\title{
Middle Devonian lycopsids from high southern palaeolatitudes of Gondwana (Argentina)
}

\author{
CARLOS A. CINGOLANI*, CHRISTOPHER M. BERRY†, \\ EDUARDO MOREL $\$$ \&ENATA TOMEZZOLI§
}

\begin{abstract}
*Centro de Investigaciones Geológicas y Museo de La Plata, calle 1 n. 644, La Plata, Argentina $\dagger$ Department of Earth Sciences, Cardiff University, P.O. Box 914, Cardiff CF10 3YE, Wales, UK †C.I.C. Provincia de Buenos Aires \& Departamento de Paleobotánica, Museo de La Plata, Paseo del Bosque, 1900-La Plata, Argentina

$\S$ Departamento de Ciencias Geológicas, Universidad de Buenos Aires, Pabellón II-Ciudad Universitaria,
\end{abstract} 1428-Buenos Aires, Argentina

(Received 12 February 2002; accepted 16 July 2002)

\begin{abstract}
Fossil plants are described from the upper part of the Devonian Lolén Formation, Sierra de la Ventana, Buenos Aires Province, Argentina, in the area of Estancia Las Acacias. The sequence is composed mainly of dark grey shales, and fossils were found in a single horizon where thin interlayered beds of fine reddish-brown micaceous sandstones appear where the environment of marine deposition became more shallow. The age of the Lolén Formation is presently established on the basis of brachiopods, these being characteristic elements of the Malvinokaffric realm from the Gondwana Lower Devonian (Emsian). The fossil plants are remarkably preserved given that they are in rocks that have undergone intense deformation. The plants are identified as Haplostigma sp. and Haskinsia cf. H. colophylla, and suggest a Middle Devonian age (Givetian) for the fossil-bearing levels. Haskinsia, identified on the basis of leaf morphology, is the first well-delimited Middle Devonian lycopsid genus described from Argentina, and the record from the most southerly palaeolatitude. During the Middle Devonian, Haskinsia was distributed in tropical, warm temperate and high southern latitude, ?cool temperate zones.
\end{abstract}

Keywords: Devonian, Lycopsida, Argentina, Gondwana, Haskinsia.

\section{Introduction}

The record of primitive vascular plants in the Devonian of South America is generally poor, but significant progress has been made in recent years. This includes descriptions from Venezuela (e.g. Berry \& Stein, 2000; Berry, 2000; Berry \& Edwards, 1996; Edwards \& Benedetto, 1985), Colombia (Berry et al. 2000), Brazil (Gerrienne, 1999; Gerrienne et al. 2001) and Bolivia (Edwards et al. 2001a). In Argentina, the presence of Devonian plants has previously been recorded by Halle (1936), Frenguelli (1951, 1952), Menendez (1967), Archangelsky (1983), Morel et al. (1993), Gutierrez (1996), Gutierrez \& Archangelsky (1997) and Edwards et al. (2001b), although frequently age and accurate determination of the fossils is debated. For example, well-preserved leaves of Devonian lycopsids, necessary for reliable generic determination, are so far unknown. We have therefore been encouraged to try to find new localities with Devonian land plants not only because they would provide data about plant origins and evolution, but also about phytogeography on the continent of Gondwana.

$\dagger$ Author for correspondence: berrycm@cardiff.ac.uk
Beginning with the studies of Keidel (1916), du Toit (1927) and Harrington (1934, 1947), the Sierra de la Ventana region has been a key element in intercontinental correlation and geotectonic reconstruction. As a consequence of the intense deformation in the Sierra de la Ventana fold belt, fossils reported from the Devonian have so far been restricted to ichnogenera and internal casts of invertebrates (mainly brachiopods). Thus, the presence of new fossil types in the Palaeozoic sequences is a subject of particular interest.

In this contribution we present the first record of fossil plants from the Lolén Formation, of probable Middle Devonian age, constituting a novelty for the zone and for the high-latitude Gondwanan region.

\section{Previous work and geological background}

The Sierra de la Ventana range lies in the southwest of Buenos Aires Province, Argentina, between $37^{\circ}$ and $39^{\circ} \mathrm{S}$ and $61^{\circ}$ and $63^{\circ} \mathrm{W}$. The hills are made up of highly folded Palaeozoic sediments that lie on an igneous-metamorphic Neo-Proterozoic basement (Fig. 1). The sedimentary sequence is formed by three lithostratigraphic units, known as the Curamalal, Ventana and Pillahuincó groups (Harrington, 1947). The first two groups belong to Ordovician-Devonian 


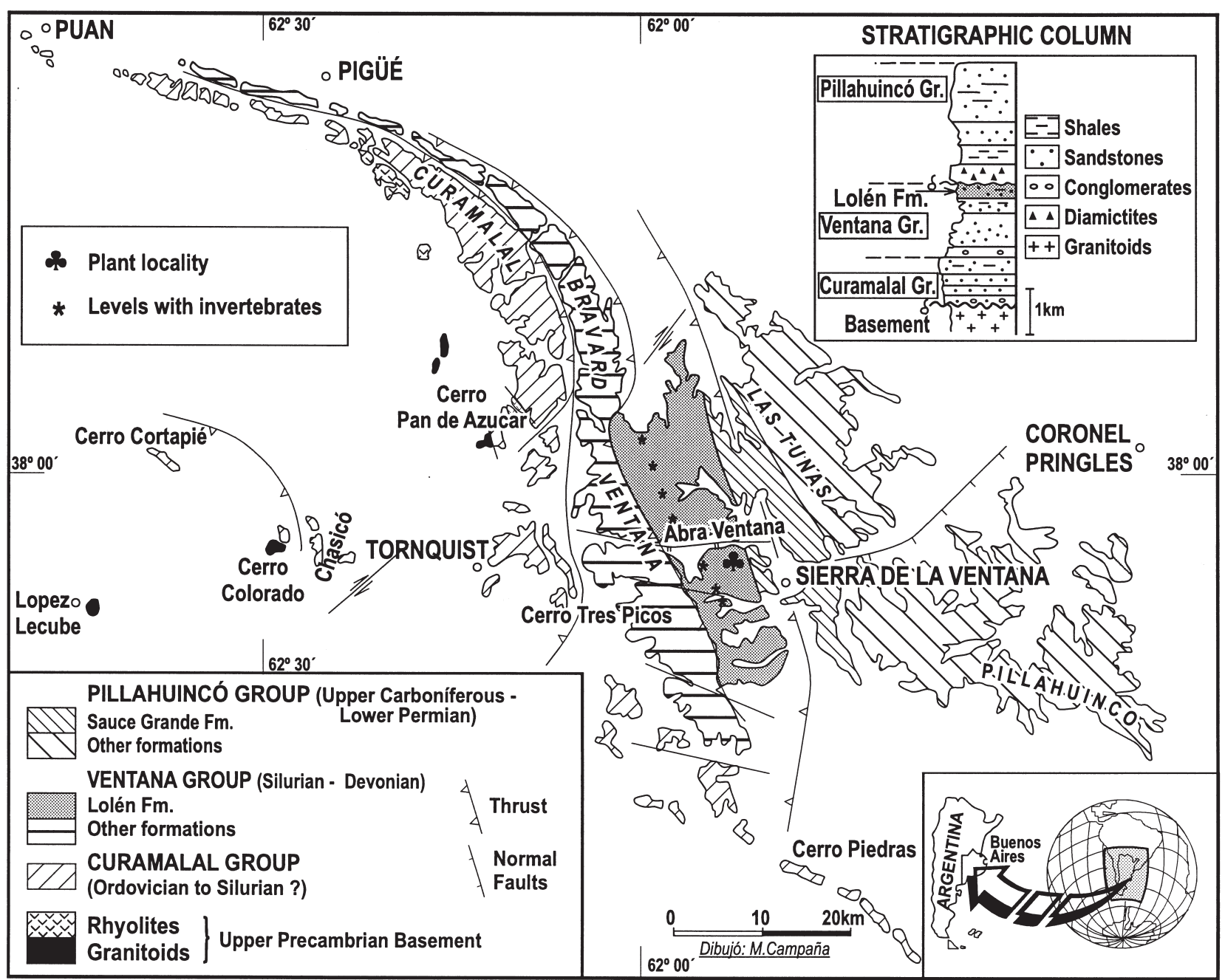

Figure 1. Location and stratigraphy of the plant-bearing locality in the Sierra de la Ventana, Buenos Aires Province, Argentina. The exact GPS locality is $38^{\circ} 04^{\prime} 02^{\prime \prime} \mathrm{S}, 61^{\circ} 52^{\prime} 40^{\prime \prime} \mathrm{W}$ (SA69 datum).

quartzitic deposits, intensely folded and SW-dipping (Cobbold, Massabie \& Rossello, 1986). Unconformable Carboniferous sediments (Massabie \& Rossello, 1984) of the Pillahuincó Group commence with diamictites from the Sauce Grande Formation (Fig. 1) demonstrating an important glacial event of Gondwanan extent (von Gosen \& Buggisch, 1989).

The Ventana Group, 1300 m thick, is made up (from base to top) of the Bravard, Napostá, Providencia and Lolén formations (Harrington, 1947, 1970). The outcrop of this group includes both the Bravard and Ventana ranges as well as the belt that lies between these ranges and the Sauce Grande river to the east (Fig. 1). The Lolén Formation, 450-600 m thick, consists mainly of lithic, feldspar-bearing, quartzose and micaceous (partly schist-bearing) sandstones, where thin-bedded interlayered pelites transformed into slates and phyllites occur. Sandstones pass upwards into thin conglomerates and thick wackes of varied colours (yellowish, greenish and red), although reddish-brown layers become predominant at the top of the unit. Slates are generally dark grey in colour. Stratification is clearly defined in tabular beds usually showing cross-bedded structures, thin lamination and ripple marks, forming a sequence representing a shallow marine clastic platform (Andreis, 1964a).

Fossils have been recorded in the Lolén Formation since 1910. Keidel (1916) recognized levels with fossil invertebrates, including brachiopods, bivalves and fragments of trilobites, and assigned to them a Devonian age. He correlated this unit with the Bokkeveld Series of the Cape Fold Belt, South Africa. These observations were confirmed and expanded by $\mathrm{du}$ Toit (1927) when he extended the correlation to the 'SAMFRAU Geosyncline' in his historic, early palaeogeographical, reassembly of the southern continents.

The first descriptions of fossils were made by G. Bonarelli and H. Harrington (cf. Harrington, 1934), who identified Cryptonella baini, Schellwienella sp. and Leptocoelia flabellites, elements that constitute an assemblage characteristic of the Lower Devonian of Gondwana (Malvinokaffric fauna). Schiller (1930) relocated the levels with invertebrates found by Keidel and increased the number of fossiliferous localities, especially for the Abra del Chaco, and demonstrated 
that they were found in a belt of sandstones and slates of about $32 \mathrm{~km}$ length (see Fig. 1).

Borrello (1962) improved the understanding of the fossiliferous levels of this unit, assigning them to a recurrent biofacies. Later, Andreis $(1964 a, b)$ made a detailed geological map of the 'zone containing brachiopods' of the Lolén Formation, analysing the local structure and demonstrating the presence of eight levels containing invertebrates that can be differentiated by textural variations. Internal casts of Cryptonella sp., Leptocoelia sp. and Derbya sp. are mentioned. The 'zone with brachiopods' was mapped by Andreis (1964a) from the Abra del Chaco to the north as far as Cerro Colorado to the south. He also presented a sedimentological study of the Lolén Formation, with accurate observations and palaeoenvironmental interpretations.

Antonioli (1966) synthesized knowledge of the fossiliferous levels, demonstrating that they are found in the lower part of the Lolén Formation at approximately 75,150 and $200 \mathrm{~m}$ from the base of the unit.

R. Tomezzoli (unpub. Ph.D. thesis, Univ. Buenos Aires, 1997; 2001), while working on the palaeomagnetism of different units in the Sierra de la Ventana, mentioned the presence of a single plant fossil in the Estancia 'Las Acacias', which she informally referred to as an 'articulated sphenophyte'. From this first discovery, and in virtue of the plan for research on primitive vascular plants of the Silurian-Devonian in Argentina (Museo de La Plata, Universidad de La Plata in co-operation with the University of Cardiff, UK), a field reconnaissance was planned in the area, which enabled us to find numerous plant remains.

\section{Materials and methods}

The new fossils were collected from the upper section of the Lolén Formation, exposed in the Estancia 'Las Acacias', a few hundred metres from the original fragment of Tomezzoli, near route 76, which joins Tornquist with Ventana Town (Fig. 1). The fossiliferous sequence is composed mainly of dark grey shales, and the fossils were found in a single bed where thin interlayered beds of fine reddish-brown micaceous sandstones appear. In this locality the beds are highly disturbed and folded and it was impossible to record a meaningful stratigraphic section. In the area under study an axial plane cleavage is recorded $\left(\mathrm{S}_{1}\right)$, which, together with stratification planes $\left(\mathrm{S}_{0}\right)$, is useful for extraction of manageable blocks.

It is worth mentioning that the plants were found in levels where the marine environment of deposition becomes increasingly shallow, sedimentological characteristics of actual continentalization being recorded (Andreis, 1964b). Afterwards, intense denudation occurred before the paraconglomerates of the Sauce Grande Formation were deposited, a similar situation to that recorded by Cuerda et al. (1990) from the Devonian of the Precordillera.

The age of the lower part of the Lolén Formation is presently established on the basis of brachiopods, these being characteristic elements of the Malvinokaffric fauna (or realm) from the Gondwana Lower Devonian (Emsian). These require palaeontological revision. The age of the upper, plant-bearing level of the formation has not previously been determined.

The plant fossils are remarkably preserved given that they occur in rocks that have undergone intense deformation. No carbon is present. The original material has been replaced by a reflectant layer of white mineral matter, possibly a clay mineral, that faithfully replicates the morphological outline of the original, yet compressed, stem and leaf tissues. The preservation is similar to that of the specimens preserved in black shale from Grahamstown, South Africa, described by Gess \& Hiller (1995). In specimens where the fracture of the rock has cleaved the centre of the stem 'compression', a pattern of discrete bumps and depressions represents the position of the leaf bases (see discussion in Berry \& Edwards, 1995). Others are cleaved along the plane of the leaf laminae.

Macrophotography was carried out using both incident and low-angle illumination in order to bring out morphology or topographic information where appropriate.

The new Haskinsia material collected by us is retained in the Departamento Paleobotánica, Museo de La Plata, Argentina, numbers LPPB 13135-13149.

\section{Palaeobotanical descriptions}

Genus Haplostigma Seward, 1932

Haplostigma sp.

Figure 2a

Material. LPPB 13150.

Description. The first plant found by Tomezzoli. A fragmentary, defoliated axis preserved as an impression (external mould) lacking counterpart, $10 \mathrm{~cm}$ long, $2 \mathrm{~cm}$ wide in a medium-grained sandstone. False leaf scars arranged in apparent helical phyllotaxis, with an angle of about $45^{\circ}$. Scars more or less circular lacking evidence of a vascular trace, approximately $2.5 \mathrm{~mm}$ across, and separated from the adjacent scars by a distance a little greater than their diameter. Leaves not preserved.

Discussion. Plant remains showing prominent false leaf scars arranged in helical phyllotaxis but lacking preserved leaf morphology (Fig. 2a) can only be assigned to a form-genus that reflects their state of preservation. In this case the somewhat coarse nature of the sediment and probable transport before deposition as well as a unfavourable tectonic regime has meant that no carbonaceous material is preserved and 

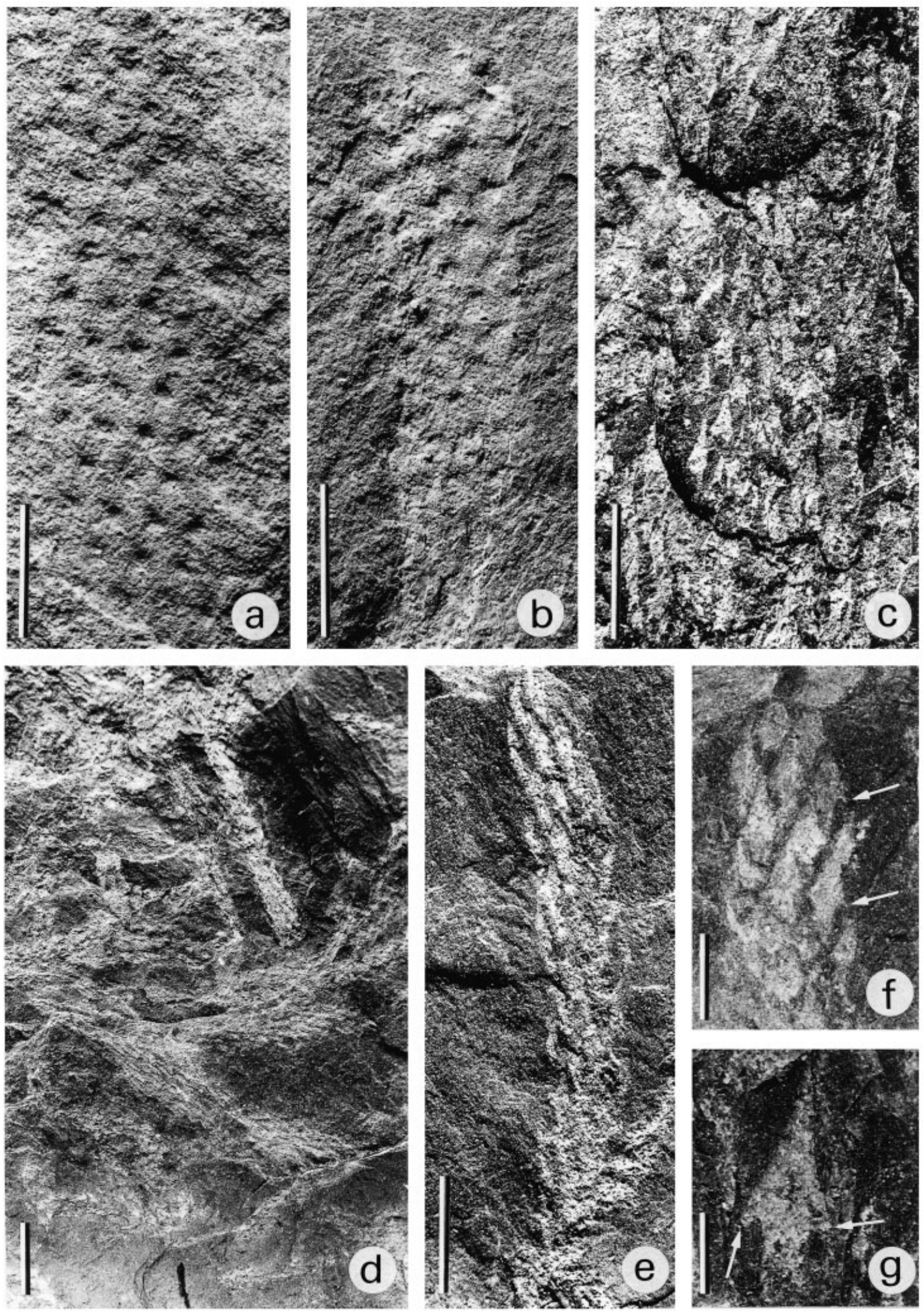

Figure 2. Haplostigma and Haskinsia from the Devonian Lolén Formation, Sierra de la Ventana, Buenos Aires Province, Argentina. (a) Haplostigma sp. Stem impression, illumination from top left. LPPB 13150. (b-g) Haskinsia cf. H. colophylla Grierson \& Banks emend. Bonamo, Banks \& Grierson. (b) LPPB 13140. Stem compound cleaved compression, showing false leaf scars (shadows) and raised areas (light) demonstrating stem tissues pushed up into swollen leaf bases on counterpart. Illumination from top left. (c) LPPB 13138. Leaf lamina cleaved compression, showing faintly preserved mass of sagittate leaves. (d) LPPB 13135. General view of numerous axes as found scattered on bedding plane. (e) LPPB 13136. Axis showing 
leaf laminae cannot be distinguished. Such remains are probably derived from small, herbaceous lycophytes with divided leaves (e.g. Colpodexylon Banks, Leclercqia Banks, Bonamo \& Grierson, Minarodendron Li) or hastate or deltate leaves (e.g. Haskinsia Grierson \& Banks) and are often referred to the form genus Haplostigma Seward (1932). Several species of Haplostigma have been described both from South Africa (e.g. Anderson \& Anderson, 1985) and from Argentina. Haplostigma furquei Frenguelli emend. Gutiérrez, 1996 from the Volcán Range, North Precordillera and Punilla Range, Givetian to mid-Late Devonian in age, has a more pronounced series of grooves on the stem surface running longitudinally between, and curving around, the leaf bases. Haplostigma baldisii Gutierrez \& Archangelsky, 1997 from the Givetian or Frasnian of the Volcán Range has leaf bases arranged in alternate longitudinal rows, but in this case some remnants of the leaves were observed, falcate beside the stem in compression. Tomezzoli's material shares some of these characteristics. However, it is scarcely distinguishable, except by size, from other material from a nearby locality which bears leaves clearly belonging to the genus Haskinsia (these fossils are described below). We therefore leave Tomezzoli's specimen in Haplostigma bearing in mind the nature of this genus as a repository of lycopsid specimens lacking definitive leaf morphology.

Genus Haskinsia Grierson \& Banks, 1983

Haskinsia cf. H. colophylla Grierson \& Banks, 1983, emend. Bonamo, Banks \& Grierson, 1988

Figure 2b-g

\section{Material (figured). LPPB 13135-13140.}

Description. The new plant remains discovered by us are in a better, but somewhat unusual, state of preservation (as described above). The plants are represented by stem fragments of up to $15 \mathrm{~cm}$ length and about $10 \mathrm{~mm}$ maximum width, arranged in a somewhat chaotic fashion on the bedding planes (Fig. 2d). Generally the stem surface itself is very poorly preserved, being represented by a stain or patch of light mineral matter on the darker matrix surface. Lowangle illumination can sometimes pick out a pattern of depressions on the stem impression surface representing the positions of leaf bases in a helical or pseudowhorled pattern (Fig. 2b). The outlines of small leaves (microphylls) are sometimes more clearly defined where the preservation is exceptionally good and the matrix is fractured at exactly the right level (Fig. 2c, e, f). The microphylls are up to $6 \mathrm{~mm}$ long in total length, being divided into a petiole and distal lamina. The petiole is up to $1.8 \mathrm{~mm}$ in length and approximately $1 \mathrm{~mm}$ wide and is enlarged very slightly distally at the base of the lamina (Fig. 2g, lower). The lamina is of a broadly elongate deltoid shape with slightly convex margins and two opposite proximally-directed tips at the basal corners (Fig. 2f, g, arrows) giving a distinctive overall sagittate outline of 3-5 mm length and $2.5 \mathrm{~mm}$ of maximum width at the base (Fig. 2f, g). When observed together on the axes these leaves have slight but characteristic overlap (Fig. 2f).

Discussion. According to the morphological characteristics observed, particularly those of leaf morphology, these fossils correspond to the genus Haskinsia Grierson \& Banks (1983) as emended by Bonamo, Banks \& Grierson (1988). The history of this genus, and probable synonymy to Artschaliphyton Senkevich, are discussed by Berry (1997).

Haskinsia was originally recorded in New York State, in sediments assigned a latest Eifelian-early Frasnian age, first under the name Drepanophycus colophyllus (Grierson \& Banks, 1963) and then as Haskinsia colophylla (Grierson \& Banks, 1983). Grierson \& Banks recognized the deltoid morphology of the leaves but did not see the downwards-pointing lateral corners of the leaves. Haskinsia was next identified in Venezuela (Edwards \& Benedetto, 1985) in deposits of Givetian age (Harvey, 1999). Edwards \& Benedetto described the extensions to the lower corner of the margins of the leaves and therefore erected the new species $H$. sagittata based on the sagittate leaf morphology as well as more minor differences in the pattern of apparent pattern of stem reinforcement tissues and lack of anatomy. Bonamo, Banks \& Grierson (1988) later recognized the sagittate morphology of leaves in their original New York specimens and emended both the species and genus diagnosis accordingly. Later material from Venezuela included the first fertile specimens of $H$. sagittata, as well as a new species $(H$. hastata) with hastate leaves (Berry \& Edwards, 1996).

Our Argentinian specimens lack any pattern of longitudinal ridges along the stem compressions, representing stem reinforcing tissues. This is probably caused by the coarse nature of the matrix as well as the lack of any remaining organic carbon. The leaf morphology is diagnostic of the genus Haskinsia (Bonamo, Banks \& Grierson 1988), a determination made with a high level of certainty. The specific determination is potentially more controversial. $H$. sagittata and $H$. colophylla differ in only small details of the stem reinforcing tissues, as well as lack of anatomy

poorly preserved stem tissues (lower) and poorly preserved sagittate leaves (upper). (f) LPPB 13137b. Slightly overlapping sagittate leaves on a single axis. Lower corners of sagittate leaves (arrows). (g) LPPB 13139. Isolated leaf, showing petiole (lower) and blade (lamina) with two downward-directed lateral tips (arrows) and acute apex. Scale bars: (a, d) $20 \mathrm{~mm},(\mathrm{~b}, \mathrm{c}, \mathrm{e}) 10 \mathrm{~mm}$, (f) $5 \mathrm{~mm}$, (g) $2 \mathrm{~mm}$. 
Table 1. Occurrences of Haskinsia and other probable/possible synonymous plants worldwide

\begin{tabular}{|c|c|c|c|c|}
\hline Species & Locality & Palaeocontinent & Age & Reference \\
\hline $\begin{array}{l}\text { Haskinsia } \\
\text { colophylla }\end{array}$ & $\begin{array}{l}\text { Various, New } \\
\text { York State }\end{array}$ & Laurussia & $\begin{array}{l}\text { Givetian-Early } \\
\text { Frasnian }\end{array}$ & $\begin{array}{r}\text { Grierson \& Banks, 1983; } \\
\text { Grierson \& Banks, } 1963\end{array}$ \\
\hline $\begin{array}{l}\text { Haskinsia } \\
\text { sagittata }\end{array}$ & $\begin{array}{l}\text { Sierra de Perijá, } \\
\text { Venezuela }\end{array}$ & Gondwana & Mid-late Givetian & Berry \& Edwards 1996 \\
\hline $\begin{array}{l}\text { Drepanophycus } \\
\text { schopfii }\end{array}$ & $\begin{array}{l}\text { Marie Byrd Land, } \\
\text { Antarctica }\end{array}$ & Gondwana & Glacial eratics & Edwards, 1990 \\
\hline $\begin{array}{l}\text { Haskinsia } \\
\text { sagittata }\end{array}$ & $\begin{array}{l}\text { Hoboksar, Xinjiang, } \\
\text { China }\end{array}$ & Kazakhstan & Givetian & Cai \& Wang, 1995 \\
\hline $\begin{array}{l}\text { Artschaliphyton } \\
\text { unicum }\end{array}$ & $\begin{array}{l}\text { Northwest Siberian } \\
\text { Platform }\end{array}$ & Siberia & ?Late Eifelian & Iurina, 1988 \\
\hline $\begin{array}{l}\text { Artschaliphyton } \\
\text { unicum }\end{array}$ & Kazakhstan & Kazakhstan & $\begin{array}{l}\text { ?Late Eifelian-- } \\
\text { Givetian }\end{array}$ & Senkevich, 1971 \\
\hline $\begin{array}{l}\text { Haskinsia } \\
\text { cf. H. colophylla }\end{array}$ & $\begin{array}{l}\text { Sierra de la Ventana, } \\
\text { Argentina }\end{array}$ & Gondwana & ?Middle Devonian & This work \\
\hline Cf. Haskinsia & Northern Morocco & Gondwana & Late Emsian & Fairon-Demaret \& Regnault, 1986 \\
\hline
\end{tabular}

in the Venezuela specimens and lack of fertile leaves in the New York material. Leaves of the New York fossils are reportedly slightly smaller than for those of the Venezuelan species and our Argentinian specimens, but variation within the assemblages is not understood perhaps as well as it should be. Also very probable tectonic deformation, including stretching, of the Argentinian fossils cannot currently be quantified, making comparisons of measurements meaningless. We therefore assign our specimens to $H$. cf. $H$. colophylla because $H$. colophylla is the type species and the first named species which has become recognized to have sagittate leaves.

The occurrence of Haskinsia at the top of the Lolén Formation suggests a Middle Devonian (Givetian) to early Frasnian age is most likely for the plant fossilbearing levels based on other occurrences of Haskinsia in which sagittate leaf morphology has been demonstrated.

\section{Palaeogeographic significance}

In addition to the New York and Venezuelan records, Haskinsia is increasingly recognized as a genus of wide distribution in the Devonian (Table 1; Fig. 3). Haskinsia sagittata with well-defined sagittate leaf morphology has been illustrated from Xinjiang, northwest China, in units belonging also to the Givetian (Cai \& Wang, 1995). Specimens referred to Drepanophycus schopfii by Grindley, Mildenhall \& Schopf (1980) from Devonian rocks of the Ruppert Coast, Antarctica, were suggested to have leaves of Haskinsia-like saggitate morphology by Edwards (1990), and this is confirmed by further recent observations of the original specimens by $\mathrm{CMB}$ and D. Edwards. Questionable specimens with incomplete deltoid rather than explicitly sagittate leaves have also been found in Emsian strata in Morocco (as cf. Haskinsia Fairon-Demaret \& Regnault, 1986). Specimens referred to Artschaliphyton Senkevich, very probably synonymous with Haskinsia on the basis of leaf morphology (Berry, 1997), are known from Siberia and Kazakhstan (Iurina, 1988; Senkevich, 1971). The many records need to be checked on a caseby-case basis to establish whether one or several taxa are involved and their exact stratigraphic occurrences.

Previous records of Haskinsia mentioned above, when plotted on a recent Middle Devonian palaeocontinental reconstruction (Eldridge, Walsh \& Scotese, 1996), are mostly restricted within $45^{\circ}$ of the palaeoEquator (Fig. 3). The new record from the Sierra de la Ventana constitutes the most southerly known Haskinsia preserved with intact leaves, about $73^{\circ} \mathrm{S}$.

Other records of lycopsids from mid- to high southerly palaeolatitudes in the Middle Devonian refer almost exclusively to records of stems from which leaves have been lost or are not preserved (e.g. Plumstead, 1967; Anderson \& Anderson, 1985; McLoughlin \& Long, 1994), and therefore, despite the profusion of form genera and species, these plants cannot be attributed to well-founded genera which are recognized on the basis of leaf morphology. There are two exceptions: firstly, a stem fragment with attached leaves from Port Alfred, Kowie, South Africa, which, although the leaves are broken, is very similar to Colpodexylon (Seward, 1903, 1909; Berry, 1997); and secondly, a stem fragment from Brazil, the leaves of which were originally described as shaped like tuning forks named Protolepidodendron kegeli (Kräusel \& Dolianiti, 1957) but which bears much resemblance to Colpodexylon and deserves reinvestigation (Berry \& Edwards, 1995).

The occurrences of HaskinsialArtschaliphyton, when mapped onto a Middle Devonian palaeocontinental reconstruction (Fig. 3), show an extremely widespread distribution. We have further added to the reconstruction palaeoclimatic zones, derived from palaeoclimate-sensitive lithologies and faunal indicators, generalized to the Middle Devonian (Scotese, Boucot \& Chen, unpub. data, 2001: http://www. scotese.com/climate.htm). In the area of Argentina there is more specific data to support warming 


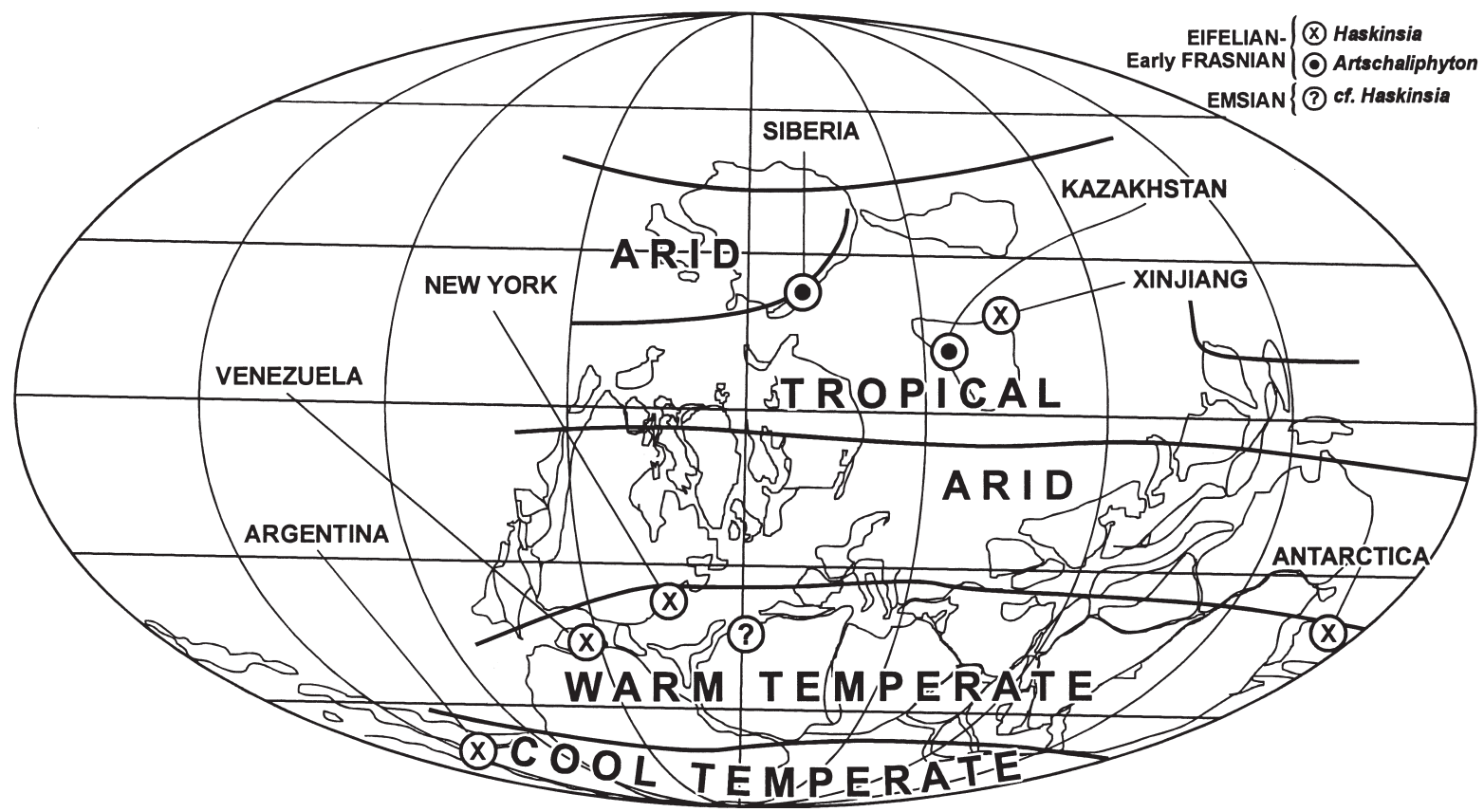

Figure 3. Occurrences of Haskinsia and Artschaliphyton on the palaeogeographic Middle Devonian map of Eldridge, Walsh \& Scotese (1996) with palaeoclimate zones from Scotese, Boucot \& Chen, unpub. data, 2001: http://www.scotese.com/climate.htm.

between Eifelian to Givetian times, including the disappearance of the cold water Malvinokaffric invertebrate faunas around the Eifelian-Givetian boundary (Boucot, 1988). The map demonstrates, within the limits of resolution of modern palaeogeographical reconstruction, the fact that Haskinsia was able to grow in areas far south of the tropical and northern part of the warm temperate zones where it had previously been found. The only zones in which this genus has yet to be found are the arid areas in north and south low-middle latitudes. Haskinsia is noticeably absent from Belgium and Germany where, despite abundant and wellpreserved floras, Leclercqia is so far the only recorded genus of Middle Devonian lycopsid recognized on the basis of leaf morphology (Fairon-Demaret, 1981).

Assuming various astronomical constants, and the accuracy of the reconstructions, our discovery is far enough south that the plants would have spent part of the year in permanent darkness or at least nothing stronger than twilight, a considerable challenge for a plant with a fleshy axis, unless the ambient environment was warm and hospitable. Living members of Lycopodiaceae (e.g. Huperzia) similarly have a distribution that ranges from arctic to tropics (Øllgaard, 1987). However, Huperzia does not have the range of leaf morphologies observed in Devonian Protolepidodendrales that hints at adaption to, or tolerance of, environmental conditions.

With so few datapoints from the macropalaeobotanical record, particularly at high latitudes, we do not yet know if our fossil represents a low-diversity high-latitude flora, or if it was part of a more diverse vegetation preserved by taphonomic chance. In localities where diverse floras have been recovered from a considerable thickness of sediments, monospecific mats of Haskinsia have been found restricted to only certain beds (Berry \& Edwards, 1996; Grierson \& Banks, 1983). Our discovery therefore remains uninformative in this regard. However, we are encouraged that identifiable macrofossil material may be found at high palaeolatitude, even in unpromising tectonic settings.

Acknowledgements. We thank Lic. Sergio Rodriguez for his helpful assistance during the field trip, the Comisión de Investigaciones Científicas de la Provincia de Buenos Aires (CIC) for funding, the Nuffield Foundation (Newly Appointed Lecturers Scheme) for fieldwork support for $\mathrm{CMB}$, and Prof. Dianne Edwards for suggestions and comments. Art Boucot is thanked for palaeobiogeographical help. Muriel Fairon-Demaret and an anonymous reviewer made helpful suggestions.

\section{References}

Anderson, J. M. \& Anderson, H. M. 1985. Palaeofloras of Southern Africa. Prodromus of South Africa megafloras, Devonian to Lower Cretaceous. Rotterdam: Balkema, $423 \mathrm{pp}$.

ANDREIS, R. R. 1964a. Informe sobre el estudio de la zona con braquiópodos del Grupo de Lolén (Sierra de la Ventana, prov. Buenos Aires). Notas Comisión de Investigación Científica de la Provincia de Buenos Aires 2(5), 1-10.

Andreis, R. R. 1964b. Petrología del Grupo Eodevónico de Lolén, Sierras Australes (Provincia de Buenos Aires). Anales Comisión de Investigación Científica de la Provincia de Buenos Aires 5, 79-124.

Antonioli, J. A. 1966. Listas de fósiles del Paleozoico de la provincia de Buenos Aires. Las localidades de sus hallazgos e historia de los mismos. Anales Comisión de 
Investigación Científica de la Provincia de Buenos Aires. 1966, 47 pp. La Plata.

ARCHANGElSKY, S. 1983. Una nueva licophyta herbácea del Devónico de las Islas Malvinas, Argentina. Revista Técnica YPFB 9, 129-35.

BERRY, C. M. 1997. Diversity and distribution of Devonian herbaceous lycopsids. The Palaeobotanist 45, 209-19.

BERRY, C. M. 2000. A reconsideration of Wattieza Stockmans (here attributed to Cladoxylopsida) based on a new species from the Devonian of Venezuela. Review of Palaeobotany and Palynology 112, 125-46.

BERRY, C. M. \& EDWARDS, D. 1995 . New species of the Devonian lycophyte Colpodexylon from the Devonian of Venezuela. Palaeontographica B 237, 59-74.

BerRY, C. M. \& Edwards, D. 1996. The herbaceous lycophyte Haskinsia Grierson and Banks from the Devonian of western Venezuela, with observations on leaf morphology and fertile specimens. Botanical Journal of the Linnean Society 122, 103-22. London.

Berry, C. M. \& Stein, W. E. 2000. A new iridopteridalean from the Devonian of Venezuela. International Journal of Plant Sciences 161, 807-27.

Berry, C. M., Morel, E., Mojica, J. \& Villarroel, C. 2000. Devonian plants from Colombia, with discussion of their geological and palaeogeographical context. Geological Magazine 137, 257-68.

Bonamo, P. M., Banks, H. P. \& Grierson, J. D. 1988. Leclercqia, Haskinsia, and the role of leaves in delineation of Devonian lycopod genera. Botanical Gazette 14, 222-39.

Borrello, A. V. 1962. Sobre los niveles fosilíferos del Devónico inferior de las Sierras Australes de la provincia de Buenos Aires. Notas Comisión de Investigación Científica de la Provincia de Buenos Aires 1(4), 1-9.

Boucot, A. 1988. Devonian biogeography: an update. In Devonian of the World (eds N. J. McMillan, A. F. Embry and D. J. Glass), pp. 211-27. Canadian Society of Petroleum Geologists, Memoir 14 (III). Calgary: CSPG.

Cai Chongyang \& Wang Yi. 1995. Devonian Floras. In Fossil floras of China through the geological ages (ed. Li Xingxue), pp. 28-77. Guangzhou, China: Guangdong Science and Technology Press.

Cobbold, P. R., Massabie, A. \& Rossello, E. 1986. Hercynian wrenching and thrusting in the Sierras Australes Foldbelt, Argentina. Hercynica 2(2), 135-48.

Cuerda, A. J., Arrondo, O. G., Morel, E. M. \& Spalletti, L. A. 1990. Procesos de continentalización en el Devónico de la Precordillera. Revista del Museo de La Plata (Nueva Serie) 10(89), 185-95.

Du Toit, A. L. 1927. A Geological comparison of South America with South Africa. With a paleontological contribution by F. R. Cowper Reed. Carnegie Institution of Washington, Publication no. 381, 157 pp.

EDwARDS, D. 1990. Silurian-Devonian Paleobotany: Problems, Progress, and Potential. In Antarctic Paleobiology. Its role in the Reconstruction of Gondwana (eds T. Taylor and E. Taylor), pp. 89-101. New York: Springer Verlag.

Edwards, D. \& BenedetTo, J. L. 1985. Two new species of herbaceous lycopods from the Devonian of Venezuela with comments on their taphonomy. Palaeontology 28, 599-618.

Edwards, D., Morel, E., Paredes, F., Ganuza, D. G. \& ZÚNIIGA, A. 2001a. Plant Assemblages from the Silurian of southern Bolivia and their palaeogeographic signifi- cance. Botanical Journal of the Linnean Society $\mathbf{1 3 5}$, 229-50.

Edwards, D., Morel, E., Poiré, D. G. \& Cingolani, C. A. 2001b. Land plants in the Devonian Villavicencio Formation, Mendoza Province, Argentina. Review of Palaeobotany and Palynology 116, 1-18.

Eldridge, J., Walsh, D. \& Scotese, C. R. 1996. Plate Tracker for Windows v. 2. 0. Paleomap project. Arlington, Texas. PALEOMAP Project, 700 Tanglewood Lane, Arlington, Texas 76012, USA.

FAIRON-DEMARET, M. 1981. Le genre Leclercqia Banks, H. P., Bonamo, P. M. et Grierson, J. D. 1972 dans le Devonien Moyen de Belgique. Bulletin de l'Institut Royal des Sciences Naturelles de Belgique 31-XII, 1-10.

Fairon-Demaret, M. \& Regnault, S. 1986. Macroflores dévoniennes dans le Nord du Maroc. Annales de la Societé Geologique de Belgique 109, 499-513.

Frenguelli, J. 1951. Floras devónicas de la Precordillera de San Juan. Revista Asociación Geológica Argentina 6(2), 83-94.

Frenguelli, J. 1952. "Haplostigma furquei" n. sp. del Devónico de la Precordillera de San Juan. Revista Asociación Geológica Argentina 7(1), 298-335. Buenos Aires.

GERRIENNE, P. 1999. Lower Devonian plant messofossils from the Paraná Basin, Brazil: general introduction, description, age significance and correlation with floral succession from Laurussia and Gondwana. Workshop on Ordovician/Devonian palynostratigraphy in Western Gondwana: update, problems and perspectives. Rio de Janeiro, 1999. Abstracts, 23-35.

Gerrienne, P., Bergamaschi, S., Pereira, E., Rodrigues, M. \& Steemans, P. 2001. An early Devonian flora, including Cooksonia, from the Paraná Basin (Brazil). Review of Paleobotany and Palynology 116, 19-38.

Gess, R. W. \& Hiller, N. 1995. A preliminary catalogue of fossil algal, plant, arthropod, and fish remains from a Late Devonian black shale near Grahamstown, South Africa. Annals of the Cape Provincial Museums, Natural History 19, 225-304.

Grierson, J. D. \& BAnKs, H. P. 1963. Lycopods of the Devonian of New York State. Palaeontographica Americana 4, 220-95.

Grierson, J. D. \& Banks, H. P. 1983. A new genus of lycopods from the Devonian of New York State. Botanical Journal of the Linnean Society 86, 81-101.

Grindley, G. W., Mildenhall, D. C. \& Schopf, J. M. 1980. A mid-Late Devonian flora from the Ruppert Coast. Marie Byrd Land. West Antarctica. Journal of the Royal Society of New Zealand 10, 271-85.

Gutierrez, P. R. 1996. Revisión de las licopsidas de la Argentina. 2. Malanzania Archangelsky, Azcuy et Wagner y Haplostigma Seward; con notas sobre Cyclostigma Haughton. Ameghiniana 32(29), 127-44.

Gutierrez, P. R. \& ArChangelsky, S. 1997. Haplostigma baldisii sp. nov. (Lycophyta) del Devónico de la Precordillera de San Juan, Argentina. Ameghiniana 34(3), 275-82.

Halle, T. G. 1936. Notes on the Devonian genus Sporogonites. Svensk Botanisk Tidskrift 30, 613-23.

HARrington, H. J. 1934. Sobre la presencia de restos de la flora de "Glossopteris" en las Sierras Australes de Buenos Aires y su significación en lo referente a las relaciones de la Serie Glacial y series superiores. Revista Museo de La Plata 34, 303-38.

Harrington, H. J. 1947. Explicación de las Hojas 
Geológicas $33 \mathrm{~m}$ y $34 \mathrm{~m}$, Sierras de Curamalal y de la Ventana, Provincia de Buenos Aires. Servicio Nacional Minero Geológico, Boletin no. 61, 43 pp.

Harrington, H. J. 1970. Las Sierras Australes de Buenos Aires, República Argentina. Cadena Aulacogénica. Revista de la Asociación Geológica Argentina 25, 151-81.

Harvey, C. 1999. Middle and Upper Devonian palynology of the Sierra de Perijá, western Venezuela. Palaeontological Association Newsletter 42, supplement p. 20.

IURINA, A. L. 1988. The Middle and Upper Devonian floras of northern Eurasia. Transactions of the Palaeontological Institution, Academy of Sciences SSSR, Moscow and Leningrad, 175 pp. (in Russian).

KeIDEL, H. 1916. La geología de las sierras de la provincia de Buenos Aires y sus relaciones con las montañas de Sudáfrica y los Andes. Anales Ministerio Agricultura, Sección Geología 9(3).

Kräusel, R. \& Dolianiti, E. 1957. Restos vegetais das camadas Picos, Devoniano Inferior do Piauí. Boletim Divisão de Geologia e Mineralogia 173, 3-19.

Massabie, A. \& Rossello, E. 1984. La discordancia preFormación Sauce Grande y su entorno estratigráfico. Sierras Australes de Buenos Aires, Argentina. IX Congreso Geológico Argentino, Actas I, 337-52.

McLoughlin, S. \& Long, J. A. 1994. New record of Devonian plants from southern Victoria Land, Antarctica. Geological Magazine 131, 81-90.

Menendez, C. A. 1967. Guia Paleontológica Argentina. Parte I. Paleozoico, secciòn 7: floras Devónicas. Publicación Consejo Nacional de Investigaciones Científicas y Tecnicas (CONICET), 30 pp. Buenos Aires.
Morel, E., Cingolani, C. A., Varela, R. \& Zúñiga, A. 1993. Devonian and Lower Carboniferous plants remains from the northern Precordillera, La Rioja Province, Argentina. XII International Congress on Geology on Carboniferous and Permian. Buenos Aires, 1991. Comptes Rendus 2, 127-40. Buenos Aires.

ØllgaARD, B. 1987. A revised classification of the Lycopodiaceae s. lat. Opera Botanica 92, 153-78.

Plumstead, E. P. 1967. A general review of the Devonian fossil plants found in the in the Cape. Palaeontologia Africana 10, 1-83.

SCHILLER, W. 1930. Investigaciones geológicas en las montañas del sudoeste de la provincia de Buenos Aires. Anales Museo de La Plata, Serie 2da., 4, 9-101.

Senkevich, M. A. 1971. New Devonian Lycopodiales. Materialy po Geologii I Poleznym Iskopaemym Yuzhnogo Kazakhstana 4(29), 88-92.

Seward, A. C. 1903. Fossil floras of Cape Colony. Annales of the South Africa Museum 4(1), 1-122.

SEward, A. C. 1909. II. Notes on fossil plants from the Witteberg Series of Cape Colony. Geological Magazine V 6(545), 582-5.

SEward, A. C. 1932. Fossil plants from the Bokkeveld and Witteberg Series of Cape Colony. Quarterly Journal of the Geological Society of London 88, 358-69.

Tomezzoli, R. N. 2001. Further palaeomagnetic results from the Sierras Australes fold and thrust belt, Argentina. Geophysical Journal International 147, 356-66.

Von Gosen, W. \& Buggisch, W. 1989. Tectonic evolution of the Sierras Australes fold and thrust belt (Buenos Aires Province, Argentina) - an outline. Zentralblatt für Geologie und Paläeontologie 1, 947-58. 